\title{
GAME-BASED DESIGN MATHEMATICS ACTIVITIES AND STUDENTS' LEARNING GAINS
}

\author{
Janneth Q. RONDINA \\ University of Science and Technology of Southern Philippines \\ jannethqrondina@gmail.com \\ https://orcid.org/0000-0002-3880-9644 \\ Dennis B. ROBLE \\ University of Science and Technology of Southern Philippines \\ dennisroble@gmail.com \\ https://orcid.org/0000-0001-8322-7064
}

\begin{abstract}
The study was a quasi - experimental research conducted to investigate the effect of game-based design activities on students' achievement scores in Algebra. The participants of the study were the two sections of the junior high school students at Misamis Oriental General Comprehensive High School ,Cagayan de Oro City, Philippines. One section was assigned as control group who was exposed to traditional approach with usual motivation and varied activities given to them such as board works, seat works, assignments and weekly quiz while the other one was experimental group which was exposed to game activities locally called as "A Line For Win" and "Slide A Picture".
\end{abstract}

Keywords: mathematics game-based design activities, achievement, Algebra

\section{OYUN TABANLI TASARIM MATEMATIK ETKINLIKKLERİ VE ÖĞRENCILLRİN ÖĞRENME KAZANÇLARI}

\section{Öz}

Çalışmada oyun tabanlı tasarım faaliyetleri etkisini araştırmak için deneysel araştırma yapılmıştır. Katılımcılar Misamis Oriental genel kapsamlı lise, Philippines Cagayan şehri ortaokul öğrencileri olmak üzere iki bölümden oluşmaktadır. Çalışmanın bir bölümünde her zamanki motivasyon ile geleneksel yaklaşımlar ortaya çıkmıştır. Elde edilen veriler test yoluyla elde edilmiştir. İşlemden önce ön-test ve başarı testi uygulanmıştır. Ortalama, standart sapma ve kovaryans analizi verileri çözümlemek için kullanılmıştır. Ön test ve son testler oyun tabanlı faaliyetleri belirlemek için ölçüt olarak görev yapmıştır. Verilerde öğrencilerin başarı puanları önemli farklılıklar göstermiştir.

Anahtar kelimeler: Matematik tabanlı oyun tasarım faaliyetleri, başarı, cebir

\section{INTRODUCTION}

In the past three decades teachers instructional technique has been viewed to be one of the key components for teaching-learning process. It was used as a tool to measure of academic gains. Despite instituting measure such as teachers professional development, students performance in high stake achievement test remain low. It implies that students academic gain cannot only be attributed to teachers 'professional development and standard curricula but also in the teaching strategy that the teachers applied during the learning - teaching process. Teaching mathematics is a process, where the teachers assist the learner to develop particular thinking. Instructional games may aid in the process because it foster discussions among the players, also each member can solicit from the group the required mathematics concepts needed for the game. Discussing among the group about what happen and reflecting on the effect of the actions that were involved helped students retain the concepts in their mind (Boober 2007). Simpson (2011) mentioned that games are motivational tools especially 
for the at-risk students and for promoting healthy competition. He made use of mathopoly (the mathematics version of monopoly game) in teaching mathematics to the students. The students were motivated to participate in the game and able to apply the mathematics concepts required in playing. Hoffman and Snapp (2012) stated that games can be used to illustrate mathematical ideas. They have proven that the use of a die game could make an understanding of the connection between relative frequency and probability easier for the students. (Turgut \& Dogan Temur, 2017) in their study on the effect of game-assisted mathematics education on academic achievement in Turkey revealed that using game in teaching mathematics had appositive effect on students achievement. Griss (2013) believed that outdoor activities which involved physical activities construct memories connected to time, place and emotions, which are called episodic encoding. The students activate and integrate physical, emotional and cognitive responses to what they are learning, making it more meaningful. In this context, the researcher conducted a pretest- posttest quasi- experimental study which made use of mathematical games to determine its effect on the students' achievement score towards algebra.

\section{THEORETICAL UNDERPINNINGS}

Teaching technique plays an important role in students learning process. This study lends on the theory of Jerome Bruner (1960,1966, 1996), on instructional scaffolding which explained that students may perform better as long as appropriate guidance and learning resources that will fit their needs are given to them. In the mathematics class, aside from the teachers, the mathematically inclined students may serve as a guide for the students during the exploratory activities. Also learning resources that best fit to the students level of maturity such as manipulative and any other material to be used in the game playing may aid to better achievement. Dewey (1976) in his theory of learning by doing, cited that learning would be gained through activities at first hand experience in the life-like situation. In this study, the mathematical games were introduced to develop mastery of the computational skills and played personally by the students. In this process, students easily recall the mathematical concepts used in the game. Their actions in the game and some other responses that made them win or loss the game can helped them recall the mathematical concepts used in the game. Games are very attracted to the majority of the students and also it involves interactions with peers during the game process. Lev Vygotsky (1978), the theory zone of proximal development (ZPD ) explained that at first, a student will learn a new skill or solve a new problem with the help of an expert, however after given enough supervision, the student will be able to perform similar task alone but its not as well as the expert.

\section{INSTRUCTIONAL SCAFFOLDING FOR THE CONTROL AND EXPERIMENTAL GROUPS}

\section{“A LINE TO WIN"}

A Line To Win was intended to develop mastery of the computational skills of the students on the topics relative to quadratic functions. The game was played by two groups which took turned of serving as a host and a players. For the host group, four students were assigned as the bearers of the letters A,B,C, and D. They stayed in one line and arranged themselves in alphabetical order with one meter distance from each other so that it would be easy to determine the students who choose them during the game. Four students took charge of recording the individual scores and the remaining members of the group served as guards. There should be at least one recorder and one guard in every line (A,B,C,D ). The recorders brought with them the score sheet with the names of the players and helped each other to monitor and record the scores of the individual player. They marked $\mathrm{x}$ to the names of the students who got a wrong answer and eliminate him after committing 3 mistakes. They also compute the group and individual scores after the game. The guards kept the area suitable for the play. They kept the intruders away from the playing ground to avoid disturbances. They also watched the players to preserve the validity of the result. They assured that players who were eliminated the game cannot re-enter the playing ground again. A line to win was just similar to the multiple choice test but only it was played outside the classroom and also the students will have to form a line by 
joining the students who brought the letter with a correct answer. During the game proper, the host read the question one at a time so with the options, and the time limit to answer it. The players then answer the given question then form a line on the letter that bears the correct answer.

\section{"SLIDING A PICTURE"}

The game "Sliding a Picture" was intended to master the sketch of the graphs of quadratic function as it shifted to any vertices and as it change its opening. The game was played by using a pre-cut graphs of quadratic functions with different colors and a one whole manila paper with one big Cartesian plane drawn in it. . Yellow for $y=1 / 2 x^{2}$, green for $y=x^{2}$, blue for $y=2 x^{2}$, red for $y=3 x^{2}$, black for $\mathrm{y}=4 \mathrm{x}^{2}$, and white for $\mathrm{y}=5 \mathrm{x}^{2}$. The game was played by sliding the pre- cut graph in a Cartesian plane to illustrate the graph of a given function. For example show the graph of $y=-x^{2}$, in this case the player will use the green parabola and illustrate the graph of $y=-x^{2}$ in the big construction paper which has one big Cartesian plane.

\section{LITERATURE REVIEW}

Mathematics educators motivate students to engage in the teaching-learning process. It is observed that when the students had the focus during the discussion of mathematical concept, their scores in the test was high. However, getting the attention and engagement of the majority of the students during the discussions was difficult. It needs an activities that will catch their interest. Mathematical games have become an interesting area in educational research. Bragg (2006) stated that games develop the interest of children in learning mathematics through anticipation of competition, challenge, and fun. She further said that students felt comfortable with game-playing and were interested in developing their skills and strategies for winning, and that their desire to win encourage them to study in advance mathematical concepts. In fact, the students interviewed revealed that they were able to share strategies they had developed that highlighted their emerging understanding of the relevant mathematical concepts.

In the study conducted by Osman \& Bakar (2012) in Malaysia, they stated that by being actively involved in the Mathematics Day or any outdoor event that promotes mathematical thinking and learning, communication skill and ability to do mathematics can come together and incorporate with each other. Furthermore, they said that the teachers indicated that participating students had fun and enjoyed all kinds of games presented. The exposure they get from joining the event might gear towards communicating mathematics on their own or with the guidance from their teachers.

Taclay (2013) in his study on the on the effects of mathematical games to the achievement of scores of the students in geometry in Nueva Viscaya, Philippines revealed that the students who were exposed to mathematical games strategy had obtained a higher achievement scores compared to students who were exposed to traditional method. He recommends to use mathematical games strategy in presenting and discussing lessons in Geometry so that the students will be able to understand and internalized the mathematical the concepts and eventually obtained a higher grades. This is also supported by the resutls of the study of Abonyi, Maduagwuna \& Ugama (2014) on the effect of mathematical games on students achievement in quadratic expressions revealed that the mathematical game approach is superior compared to the conventional method. Their study also revealed that mathematical game approach resulted to a higher achievements in mathematics particularly in the topic quadratic expression. Anderson (2016) also posted that playing mathematical games encourage strategic and logical thinking. It also develop problem solving skills and mathematical fluency. Games also give the chance for students to apply their learning in a different context. Through mathematical games, students has the opportunity to discuss with their peers freely and without fear the mathematics needed in the game. Furthermore, Lee (2009) in his study on enhancement of students understanding of fractions by playing games which showed that playing games enhanced students' understanding of representations of fractions in rectangular divided quantity diagrams. However, they suggested that the learning outcome should be specific especially when the game was played as a one-off activity in the classroom. The game could be further expanded to provide in-depth 
learning that covers various types of representations of fractions, more fractions close to a half and one, and strategies of ordering fractions.

Digital and online video games are also popular nowadays and it also revealed significant improvement on students learning gains not only in mathematics but also for other disciplines. Pathiratne (2015) conducted a study on instigating and evaluation of an online game as mathematics learning support tool for elementary and middle school mathematics and the results designated that the students' opinion about the game was positive, and suggest that with some extensions the game could be utilized as an efficacious learning implement. Katmada, Mavridis \& Tsiatsos (2014) presented the design and development of the prototype of a configurable online 2D game, aimed at assisting the educator in the teaching of primary and secondary school Mathematics. Furthermore, the prototype was evaluated through a pilot study and a long-term intervention in real school settings, in order to assess its usability aspects and to find any possible flaws. According to the results of the two evaluation studies, the students' opinions about the game were mostly positive, and they considered it to be a useful and engaging learning tool, regardless of age and gender. Furthermore, concerning the game's usability, most of its features elicited average to positive responses from the students and the educators alike. Moreover, the educators encountered no difficulties in configuring the game, and the planned educational activities were concluded successfully. Thus, it was deduced that the particular game could actually be successfully incorporated and used by educators as a supplementary tool for the teaching of formal curricular material. Drigas \& Pappas (2015) examined the most representative studies over the last decade, which investigated the contribution of video games or educational video games in mathematics education. Video game-based learning seems to have positive effect on students' mathematical skills, as well on students' cognitive and mental skills. At the same time, educational math video games could motivate students' towards the course of mathematics. As revealed by surveys, video games could constitute useful auxiliary learning tools, in order to build an innovative teaching model. However, further investigation is required on the educational content that video games afford, as well as the feasibility on their utilization in the classroom. The above studies mentioned indicated the positive influence of mathematics game-based design activities either in offline or online platform. The present study investigated the offline game-based design activities which particularly aimed at enhancing students' achievement scores in Algebra.

\section{DATA GATHERING PROCEDURES}

The data of the study was collected using a teacher-made questionnaire. At the start of the study, pretest was given to both control and experimental groups in the same day. After the pretest, the treatment started. During the treatment period, the teacher discussed the concepts and after the discussion a series of activities such as seat works, board works and assignments were given to the control group while game activities such as "A Line For Win" and "Slide A Picture" were conducted in the experimental group. Also, every section was divided into six groups for the group activities after the discussions of the lessons. Upon grouping the teacher ensured that at least there was one member of the group who was mathematically inclined. After the discussions of the competencies, posttest was given to the both groups. The data collected during the pretest and posttest were analyzed using mean and standard deviation to described the data, while analysis of covariance (ANCOVA) was used to determine significant difference in the achievement test scores. Pretest was used as covariate and posttest was used as criterion.

\section{RESULTS AND DISCUSSION}

The pretest and posttest achievement scores of the students from the control (teaching without games) and the experimental group (teaching with game-based design activities) was shown in the following the table.

Table 1. Summary of Mean and Standard Deviation

\begin{tabular}{|c|c|c|c|c|}
\hline \multirow{2}{*}{ Groups } & \multicolumn{2}{|c|}{ Pretest } & \multicolumn{2}{|c|}{ Posttest } \\
\cline { 2 - 5 } & Mean & $\begin{array}{c}\text { Standard } \\
\text { Deviation }\end{array}$ & Mean & $\begin{array}{c}\text { Standard } \\
\text { Deviation }\end{array}$ \\
\hline
\end{tabular}




\begin{tabular}{|c|c|c|c|c|}
\hline $\begin{array}{c}\text { Mathematics Teaching with Game- } \\
\text { based Design Activities }\end{array}$ & 16.46 & 2.86 & 27.26 & 3.00 \\
\hline $\begin{array}{c}\text { Conventional Method of Teaching } \\
\text { Mathematics }\end{array}$ & 16.51 & 1.79 & 20.29 & 3.68 \\
\hline
\end{tabular}

Table 1 showed the mean and Standard Deviation of the achievement scores in Algebra of the students in Experimental and Control groups. The data revealed that the mean of the experimental and control group during pretest were almost identical. This implies that the students in both experimental and control groups were comparable in terms of their achievement scores which indicates that these groups possess prior knowledge on Algebra topics whihe they might have encountered in their early years in high school and the trainings they gained from mathematics enhancement program of the school. With regard to the spread of the scores, the experimental group had a Standard Deviation of 2.86 while the control group had 1.79 . This implied that the scores of the students in the control group were less spread compared to the scores of the students in the experimental group. With this result, we can infer that the students in the control group had a homogeneous knowledge in Algebra compared to the students in the experimental group whose scores had a wider spread. In the posttest, the table revealed that the mean of the experimental and control groups differs by 6.97 in favor of the experimental group. This implied that the students who were exposed to mathematical game activities had a better achievement scores than the students who were exposed to the traditional method of teaching. The result can be attributed to the integration of game activities in teaching mathematics which found to have positive effect on the student achievement (Turgut \& Dogan Temur, 2017). With regard to the variability of the scores, the experimental group had a Standard deviation of 3.0 while 3.68 for the control group. It implied that the scores of the students in experimental group were more compressed compared to the students in the control group. Also, the result we can say that the students in the experimental group had the same learning and retention on the lessons that were tackled. To verify whether the difference was significant ANCOVA was further used.

Table 2. Analysis of Covariance (Orthogonal Designs)

\begin{tabular}{|l|l|l|l|l|l|}
\hline Source of Variation & $\begin{array}{l}\text { Degress of } \\
\text { Freedom }\end{array}$ & $\begin{array}{l}\text { Adjusted Sum of } \\
\text { Squares }\end{array}$ & $\begin{array}{l}\text { Mean } \\
\text { Square }\end{array}$ & F-value & $p$-value \\
\hline Covariate (Pretest) & 1 & 69.07 & 69.07 & 1.70 & 0.196 \\
\hline Teaching Method & 1 & 853.12 & 853.12 & 21.04 & $0.000^{*}$ \\
\hline Error & 67 & 2716.76 & 40.55 & & \\
\hline Total & 69 & 3636.34 & & & \\
\hline
\end{tabular}

* significant at $\mathrm{p}<0.05$ alpha level

The table showed the result of the analysis of covariance of the pretest and posttest scores for both control and experimental groups. The analysis yielded a computed F- value of 21.04 which was greater than the critical value 4.0 at 0.05 level of significance. This implied that there was a significant difference of the achievement scores of the students as they exposed to the two different methods of teaching. The analysis revealed that the students exposed to mathematical game activities such as "a line to win and Slide the picture" obtained a higher achievement scores compared to the students who were exposed to activities inside the classroom such as seat works, board works and assignments. The higher scores of the students in experimental group was attributed to the game activities that the students were exposed since it allowed the students to share their ideas and enjoy the game during the process. The students experiences while playing may lead them to remember the mathematical concepts used in the games. This findings supports ( Hay and Booker 2006, Booker 2007). The result implied further that mathematical game activities has a positive effect to the students achievement score in mathematics particularly quadratic functions. It was observed also that the students who were exposed to mathematical game activities had enjoyed playing and solving mathematics problem during the process. Majority of them really enjoyed the activities. Moreover, the mathematical game activities made the learning of mathematics more enjoyable even to those students who were not really good in mathematics. It developed an attitude of cooperativesm and 
sportsmanship as observed by the researcher. It also develop critical thinking fluency among students because they were assigned to solve mathematical problem using mental computation given a short period of time.

\section{CONCLUSIONS}

Based on the above findings, mathematical game-based design activities such as "A Line To Win" was an effective method to improve computational skills of the students while the "Slide A Picture" was instrumental in teaching the students the sketching of the graphs of a quadratic functions. Furthermore, the mathematics game-based design activities demonstrated a positive influence on students learning gains in Algebra. With this, teachers in mathematics may integrate game-based design activities in teaching to make the learners enjoy and arouse their interest in the process of learning and they hope that this way of learning may continue in the future in their upper level mathematics. Since this study focused only on two offline mathematics game-based design activities, teachers may also explore other games such as those digitally-based activities where adventure, simulation and strategy are inetgrated and provides sudents with animations and further analyze the impact on these strategy on students' attitude and study habits. In depth analysis may also be considered on student to student interaction during the implementation of game-based activities as well as their level of creativity in solving mathematical problems. Future research may investigate whether cooperative or competitive game-based design activities can enhance students' engagement and motivation. Finally, if its possible to create a functional prototype of an online game that can be adapted according to the educator's specific needs, then it would be more fitting. It is hoped that this study adds to the existing research on game-based design activities in mathematics and even in other courses.

Traditional teaching and teacher-centered instruction may not be totally replaced by technology enriched activities in the classroom but with the technological advances, this provided teachers and students the opportunity to create an entirely new learning environment in mathematics by significantly increasing the range and sophistication of possible classroom activities. Offline and online game-based activities in mathematics is a promising approach to be explored by teachers to ignite students' interest and motivation in learning mathematics. A longitudinal study may also offer an exciting view of the maximum impact of the use of game-based design activities in learning mathematics.

\section{REFERENCES}

Abonyi, O. S., Maduagwuna, N. M., \& Ugama, J. O. (2014). Effects of Mathematical game on students achievement in quadratic expressions. International Journal of Scientific and Engineering Research, 5(6), 678-684.

Boober, G. (2006). Developing a quality mathematics education culture: using instructional games to engage students and construct mathematical ways of thinking. Griffith University, Brisbane, Australia. Bouzid, T., Darhmaoui, H., \& Kaddari, F. (2017, March). Promoting elementary mathematics learning through digital games: Creation, implementation and evaluation of an edutainment game to promote basic mathematical operations. In Proceedings of the 2nd international Conference on Big Data, Cloud and Applications (p. 95). ACM.

Bragg, L. (2006). Students impressions of the value of games for the learning of mathematics. In Proceedings of the 30th conference of the international group for the psychology of mathematics education (pp. 217-224). International Group for the Psychology of Mathematics Education.

Drigas, A., \& Pappas, M. (2015). On line and other game-based learning for mathematics. International Journal of Online Engineering (iJOE), 11(4), 62-67.

Fischer, M. (2013). Reading Dewey's Political Philosophy through Addams's Political Compromises. American Catholic Philosophical Quarterly, 87(2), 227-243.

Ginsberg, H. et. al. (1976) . Piaget's Theory of Intellectual Development.Ohio: Charles E. Meirrel Book Inc.

Holland, R. (2004). To build a better teacher: The emergence of a competitive education industry. Greenwood Publishing Group. 
Hoffman, T. et. al. (2012). A die makes understanding the connection between relative frequency and probability easier for students. NCTM Vol 6 no. 5.

Katmada, A., Mavridis, A., \& Tsiatsos, T. (2014). Implementing a Game for Supporting Learning in Mathematics. Electronic Journal of e-Learning, 12(3), 230-242.

Lee, Y. L. (2009). Enhancement of fractions from playing a game. In Crossing divides: MERGA 32: Proceedings of the 32nd Annual Conference of the Mathematics (Vol. 1, pp. 323-330).

McLeod, S. (2008). Bruner's Three Modes of Representation. Simply Psychology.

Neill, J. (2005). 500 Word summary of Dewey's experience and education. Experential Learning.

Norton, A., Winner, E., Cronin, K., Overy, K., Lee, D. J., \& Schlaug, G. (2005). Are there pre-existing neural, cognitive, or motoric markers for musical ability?. Brain and cognition, 59(2), 124-134.

Osman, K., \& Bakar, N. A. (2012). Educational computer games for Malaysian classrooms: Issues and challenges. Asian Social Science, 8(11), 75.

Pathiratne, S (2015). Instigating an Online Game as Mathematics Learning Support Tool. 6th International Conference on Business \& Information ICBI - 2015, Faculty of Commerce and Management Studies, University of Kelaniya, Sri Lanka. pp 322-338.

Piaget, J. (1969). Science of Education and the Psychology of the Child. New York: Viking. Project Based Learning.

Rescorla, R. A., \& Solomon, R. L. (1967). Two-process learning theory: Relationships between Pavlovian conditioning and instrumental learning. Psychological review, 74(3), 151.

Skinner, B. F. (1950). Are theories of learning necessary?. Psychological review, 57(4), 193.

Simpson, A. (201 1). Mathematics Teacher. Volume 106, No. 6, 2013

Taclay, R. J. (2013). Effects of Mathematical Games Strategy on the Achievement of Students in High School Geometry. JPAIR Institutional Research, 1(1), 82-96.

Touval, A. (2011). Teaching the perpendicular bisector: A kinesthetic approach. Mathematics Teacher, 105(4), 269-273.

Tu, W. (2012). A kinesthetic approach to horizontal shift.Article. NCTM Vol. 105. No.7

Turgut, S., \& Dogan Temur, Ö. (2017). The effect of game-assisted mathematics education om academic achievement in Turkey: A meta-analysis study. International Electronic Journal of Elementary Education, 10(2), 195-206. https://doi.org/10.26822/iejee.2017236115

Vygotsky, L. (1978). Interaction between learning and development. Readings on the development of children, 23(3), 34-41.

Vygotsky, L. S. (1978). Mind in society: The development of higher mental process. 